University of Nebraska - Lincoln

DigitalCommons@University of Nebraska - Lincoln

\title{
Protective efficacy of catalytic bioscavenger, paraoxonase 1 against sarin and soman exposure in guinea pigs
}

\author{
Manojkumar Valiyaveettil \\ Walter Reed Army Institute of Research, m.valiyaveettil@amedd.army.mil \\ Yonas Alamneh \\ Walter Reed Army Institute of Research \\ Peter Rezk \\ US Army Medical Research Institute of Chemical Defense \\ Lionel Biggemann \\ Walter Reed Army Institute of Research \\ Michael W. Perkins \\ US Army Medical Research Institute of Chemical Defense \\ See next page for additional authors
}

Follow this and additional works at: https://digitalcommons.unl.edu/usarmyresearch

Part of the Operations Research, Systems Engineering and Industrial Engineering Commons

Valiyaveettil, Manojkumar; Alamneh, Yonas; Rezk, Peter; Biggemann, Lionel; Perkins, Michael W.; Sciuto, Alfred M.; Doctor, Bhupendra P.; and Nambiar, Madhusoodana P., "Protective efficacy of catalytic bioscavenger, paraoxonase 1 against sarin and soman exposure in guinea pigs" (2011). US Army Research. 156.

https://digitalcommons.unl.edu/usarmyresearch/156

This Article is brought to you for free and open access by the U.S. Department of Defense at DigitalCommons@University of Nebraska - Lincoln. It has been accepted for inclusion in US Army Research by an authorized administrator of DigitalCommons@University of Nebraska - Lincoln. 


\section{Authors}

Manojkumar Valiyaveettil, Yonas Alamneh, Peter Rezk, Lionel Biggemann, Michael W. Perkins, Alfred M.

Sciuto, Bhupendra P. Doctor, and Madhusoodana P. Nambiar 


\title{
Protective efficacy of catalytic bioscavenger, paraoxonase 1 against sarin and soman exposure in guinea pigs ${ }^{\text {in }}$
}

\author{
Manojkumar Valiyaveettil ${ }^{\mathrm{a}, *}$, Yonas Alamneh ${ }^{\mathrm{a}}$, Peter Rezk ${ }^{\mathrm{b}}$, Lionel Biggemann ${ }^{\mathrm{a}}$, Michael W. Perkins ${ }^{\mathrm{b}}$, \\ Alfred M. Sciuto ${ }^{\mathrm{b}}$, Bhupendra P. Doctor ${ }^{\mathrm{a}}$, Madhusoodana P. Nambiar ${ }^{\mathrm{a}, \mathrm{c}, *}$ \\ ${ }^{a}$ Closed Head Injury Branch, Center for Military Psychiatry and Neuroscience, Walter Reed Army Institute of Research, Silver Spring, MD 20910, USA \\ ${ }^{\mathrm{b}}$ Analytical Toxicology Division, US Army Medical Research Institute of Chemical Defense, Aberdeen Proving Ground, MD 21010, USA \\ ${ }^{\mathrm{c}}$ Department of Medicine, Uniformed Services University of the Health Sciences, Bethesda, MD 20814, USA
}

\section{A R T I C L E I N F O}

\section{Article history:}

Received 11 November 2010

Accepted 21 December 2010

Available online 8 January 2011

\section{Keywords:}

Chemical warfare nerve agents

Sarin

Soman

Catalytic bioscavenger

Paraoxonase 1

\begin{abstract}
A B S T R A C T
Human paraoxonase 1 (PON1) has been portrayed as a catalytic bioscavenger which can hydrolyze large amounts of chemical warfare nerve agents (CWNAs) and organophosphate (OP) pesticides compared to the stoichiometric bioscavengers such as butyrylcholinesterase. We evaluated the protective efficacy of purified human and rabbit serum PON1 against nerve agents sarin and soman in guinea pigs. Catalytically active PON1 purified from human and rabbit serum was intravenously injected to guinea pigs, which were 30 min later exposed to $1.2 \times \mathrm{LCt}_{50}$ sarin or soman using a microinstillation inhalation exposure technology. Pre-treatment with 5 units of purified human and rabbit serum PON1 showed mild to moderate increase in the activity of blood PON1, but significantly increased the survival rate with reduced symptoms of CWNA exposure. Although PON1 is expected to be catalytic, sarin and soman exposure resulted in a significant reduction in blood PON1 activity. However, the blood levels of PON1 in pre-treated animals after exposure to nerve agent were higher than that of untreated control animals. The activity of blood acetylcholinesterase and butyrylcholinesterase and brain acetylcholinesterase was significantly higher in PON1 pre-treated animals and were highly correlated with the survival rate. Blood $\mathrm{O}_{2}$ saturation, pulse rate and respiratory dynamics were normalized in animals treated with PON1 compared to controls. These results demonstrate that purified human and rabbit serum PON1 significantly protect against sarin and soman exposure in guinea pigs and support the development of PON1 as a catalytic bioscavenger for protection against lethal exposure to CWNAs.
\end{abstract}

Published by Elsevier Inc.

\section{Introduction}

Chemical warfare nerve agents (CWNAs) and organophosphate (OP) pesticides exert their biological effects mainly by the irreversible inhibition of acetylcholinesterase (AChE), an enzyme

\footnotetext{
is The opinions and assertions contained herein are the private views of the authors and are not to be construed as official or as reflecting the views of the Army, the Navy, or the Department of Defense, USA.

Abbreviations: PON1, paraoxonase 1; HPON1, human PON1; RPON1, rabbit PON1; OP, organophosphate; CWNA, chemical warfare nerve agent; DFP, diisopropylfluorophosphate; CPO, chlorpyrifos oxon; $\mathrm{AChE}$, acetylcholinesterase; ACh, acetylcholine; BChE, butyrylcholinesterase; p-NPA, p-nitrophenyl acetate; DTNB, dithionitrobenzoic acid; DTP, 44'-dipyridyl disulfide, 4,4'-dithiodipyridine; IsoOMPA, tetra monoisopropyl pyrophosphor-tetramide; SDS-PAGE, sodium dodecyl sulfate polyacrylamide gel electrophoresis; Sarin, 2-(fluoro-methylphosphoryl)oxypropane; Soman, 2-(fluoromethylphosphoryl) oxy-3,3-dimethylbutane.

* Corresponding authors at: 503 Robert Grant Avenue, Walter Reed Army Institute of Research, Silver Spring, MD 20910, USA. Tel.: +1 301319 9679/7307; fax: +1 3013199404 .

E-mail addresses: m.valiyaveettil@amedd.army.mil (M. Valiyaveettil), madhusoodana.nambiar@amedd.army.mil (M.P. Nambiar).
}

involved in the catabolism of neurotransmitter acetylcholine (ACh) [1-3]. The inhibition of AChE results in accumulation of ACh in the peripheral and central nervous system leading to acute cholinergic crisis. The existing pretreatments against CWNA toxicity are centered on the development of reversible cholinesterase inhibiting compounds such as pyridostigmine bromide [4]. Post-exposure treatments include AChE re-activator 2-pralidoxime, anti-cholinergic drug atropine sulfate and anticonvulsant diazepam [5-7]. But current treatments do not completely protect against CWNA induced neuropathology and behavioral deficits.

Prophylactic pre-treatment with bioscavenger enzymes such as human butyrylcholinesterase (BChE) has emerged as a promising strategy for protection against lethal doses of CWNA exposure [810]. BChE is able to scavenge the toxic CWNA and OP in the blood before they reach the target organs. The stoichiometric $1: 1$ binding of $\mathrm{BChE}$ and nerve agent diminishes its protective efficacy with lower doses of the enzyme. Researchers worldwide are now more focused on the discovery and development of catalytic bioscavenger enzymes, which are expected to hydrolyze large amounts of CWNAs and OPs without the loss of activity. Development of 
catalytic bioscavenger will reduce the amount of purified enzyme required for treatment, and lesser demands on future logistics and resources for military operational medicine.

A promising catalytic bioscavenger against CWNAs and OPs is human serum paraoxonase 1 (PON1) (EC 3.1.8.1) [11-13]. PON1 is synthesized mainly in the liver and secreted to blood to associate with high density lipoproteins, although mRNA analysis showed its presence in many other tissues $[14,15]$. The secreted human blood PON1 enzyme is 355 amino acids long with a molecular mass in the range of $43-45 \mathrm{kDa}[16,17]$. On the other hand, rabbit serum PON1 is a 359 amino acid long protein with $85 \%$ identity to human serum PON1 [18-20]. Both human and rabbit serum PON1 exhibit multiple types of polymorphisms which affect the catalytic activity of the enzyme [21-23].

Purified human and rabbit serum PON1 was reported to hydrolyze various CWNAs and OPs in vitro [11-13,17]. Human recombinant PON1 expressed in Escherichia coli and Trichoplusia ni larvae also showed similar hydrolysis of substrates [11,24,25]. We have recently shown that purified human and rabbit serum and recombinant human PON1 efficiently hydrolyze nerve agents tabun, sarin and soman under in vitro conditions [26]. Furthermore, we demonstrated that the CWNA hydrolysis activity in the purified enzyme is intrinsic to PON1 activity and PON1 acts as a catalytic bioscavenger.

Evaluation of the in vivo efficacy of purified PON1 pre- or postexposure treatment in mice showed significant protection against chlorpyrifos oxon (CPO) [27]. Further investigations using PON1 knock-out mice showed dramatic increase in the sensitivity to $\mathrm{CPO}$ toxicity [28]. Endogenous expression of PON1 in mice using adenovirus vector or naked PON1 DNA administration also showed significant expression and protection against chlorpyrifos, diazoxon and soman induced toxicity [29-31]. In vivo evaluation of protective efficacy of PON1 has been described in mice using other OPs and injury models [32-35].

The objective of this study was to evaluate the protective efficacy of purified human and rabbit serum PON1 against sarin and soman exposure in a guinea pig inhalation model. Microinstillation inhalation exposure that is well established in our laboratory was used to endotracheally aerosolize the CWNAs $[36,37]$. The technology involves aerosolization of nerve agents using a microcatheter, which has several peripheral holes that pump air at the tip to aerosolize the agent delivered in the central hole. The microinstillation technology is safe, and requires minimum amount of the agent to produce a meaningful dose response. We demonstrate that pre-treatment with purified PON1 protects against nerve agent exposure.

\section{Materials and methods}

\subsection{Materials}

Phenylacetate, p-nitrophenylacetate (p-NPA), acetylthiocholine, butyrylthiocholine, tetra monoisopropyl pyrophosphortetramide (iso-OMPA), huperzine A, dithionitrobenzoic acid (DTNB), 4,4'-dipyridyl disulfide, 4,4'-dithiodipyridine (DTP), heparin, and PON1 polyclonal antibody were purchased from Sigma (St. Louis, MO). Tissue protein extraction reagent and BCA assay kit for protein estimation were purchased from Pierce (Rockford, IL). Microplates (96-well) were purchased from BD Biosciences (San Jose, CA). SDS-PAGE running and transfer buffer, 4-20\% Trisglycine gradient gel, and protein molecular weight marker was purchased from Invitrogen (Carlsbad, CA). Immobilon polyvinylidene difluoride membrane was purchased from Millipore (Billerica, MA). Enhanced chemiluminescence reagent was purchased from GE Healthcare (Piscataway, NJ). Telazol was purchased from Wyeth Pharmaceuticals (Madison, NJ). Meditomidine was obtained from Pfizer Pharmaceuticals (New York, NY). Chemical warfare nerve agents sarin and soman were obtained from US Army Medical Research Institute of Chemical Defense (USAMRICD), Aberdeen Proving Ground, MD.

\subsection{Animals}

All animal research was conducted in compliance with the Animal Welfare Act and other federal statutes and regulations relating to animals and experiments involving animals and adhered to principles stated in the Guide for the Care and Use of Laboratory Animals (NRC Publication 1996 edition). All animal procedures were performed at USAMRICD with an IACUC approved protocol. Male Hartley guinea pigs (250-300 g) from Charles River Laboratories (Wilmington, MA) were used in this study.

\subsection{Purification of human and rabbit serum PON1}

Large amount of PON1 was purified from human and rabbit serum as described earlier using multiple chromatographies with modifications $[38,39]$. A brief methodology of the PON1 purification was described recently [26]. The purity of human and rabbit serum PON1 was confirmed by SDS-PAGE and immunoblotting. The catalytic activity of highly purified PON1 preparations ( $>95 \%$ pure) was analyzed by using p-NPA or phenyl acetate as substrates. Enzyme activity in units was calculated from the initial linear rates of hydrolysis of substrates ( $\mathrm{p}$-NPA or phenyl acetate) using molar extinction coefficients of p-nitrophenol $\left(18 \mathrm{mM}^{-1} \mathrm{~cm}^{-1}\right.$ at $405 \mathrm{~nm})$ or phenol $\left(1.31 \mathrm{mM}^{-1} \mathrm{~cm}^{-1}\right.$ at $\left.270 \mathrm{~nm}\right)$, respectively.

\subsection{Microinstillation inhalation exposure}

Guinea pigs were quarantined for 1 week prior to inhalation exposure to sarin and soman. Microinstillation inhalation exposure was performed in these animals as described earlier [36,37]. Briefly, guinea pigs were anesthetized using a combination of telazol ( $40 \mathrm{mg} / \mathrm{kg}$, im) and medetomidine $(0.125 \mathrm{mg} / \mathrm{kg}, \mathrm{sc})$ and intubated with a translucent polystyrene tube. The microinstillation catheter (Trudell Medical International, Canada) passed through the intubation tube and placed $2 \mathrm{~cm}$ above the bifurcation of the trachea. Sarin and soman diluted in saline was aerosolized with a pulse rate of 40 pulses/min for 2-4 min. The animals were exposed to a final concentration of $846 \mathrm{mg} / \mathrm{m}^{3}$ of sarin or $841 \mathrm{mg} / \mathrm{m}^{3}$ of soman $\left(1.2 \times \mathrm{LCt}_{50}\right)[40,41]$. Terminally ill animals were euthanized and biological samples were collected. The surviving animals were allowed to recover for $24 \mathrm{~h}$ and euthanized by exsanguination and blood and tissues were collected for biochemical analysis.

\subsection{Administration of purified human and rabbit serum PON1}

Animals were randomly divided into three groups - 1, control; 2 , human serum PON1 treated; and 3, rabbit serum PON1 treated. Prior to the experiment, ear blood $(20-50 \mu \mathrm{l})$ was collected from all the animals into heparinized tubes. Purified human ( $\sim 1 \mathrm{mg}$ protein) or rabbit ( $\sim 0.5 \mathrm{mg}$ protein) serum PON1 (50-200 $\mu \mathrm{l})$ was administered intravenously to the experimental group of animals through saphenous vein ( 5 units of enzyme per animal). After $30 \mathrm{~min}$, ear blood was again collected from these animals. Animals were exposed to sarin or soman by using the microinstillation method as described above. At the end of the experiment or at $24 \mathrm{~h}$, cardiac blood was collected into heparinized tubes followed by necropsy.

\subsection{Measurement of pulse rate and blood $\mathrm{O}_{2}$ saturation}

Blood $\mathrm{O}_{2}$ saturation and pulse rate were recorded using a pulse oximeter (Nonin Medical Instruments, Minneapolis, MN) in 
animals exposed to sarin or soman as well as PON1 pre-treated animals exposed to nerve agents. Pulse rate was recorded as beats per min (bpm) and blood oxygen as \% saturation of peripheral oxygen $\left(\mathrm{SpO}_{2}\right)$. The data were recorded at pre-intubation, postintubation, and $30 \mathrm{~s}$ intervals during and after exposure of nerve agents for $15 \mathrm{~min}$. The average values (mean \pm SEM) were plotted by using GraphPad Prism software.

\subsection{Blood PON1 activity assay}

Ear blood and cardiac blood were diluted five times with deionized water. Aliquots of diluted blood samples were incubated with $10 \mathrm{mM}$ phenylacetate in $100 \mathrm{mM}$ Tris-HCl buffer, $\mathrm{pH} 8.0$ containing $2 \mathrm{mM} \mathrm{CaCl}_{2}$. The release of phenol was measured at $270 \mathrm{~nm}$ for $5 \mathrm{~min}$ in a kinetic mode using Spectramax M5 Spectrophotometer (Molecular Devices, Sunnyvale, CA).

\subsection{AChE and BChE activity assay}

Different parts of brain (frontal cortex, hind cortex, cerebellum, mid brain and hippocampus) were homogenized with 1:7 tissue protein extraction reagent $(25 \mathrm{mM}$ bicine, $150 \mathrm{mM} \mathrm{NaCl}, \mathrm{pH} 7.6$ containing mild detergent like $0.1 \% \mathrm{TX}-100$ ) at $4{ }^{\circ} \mathrm{C}$ using a tissue homogenizer and clarified by centrifugation. Aliquots of diluted blood or tissue samples were pre-incubated with $4 \mu \mathrm{M}$ of isoOMPA for $30 \mathrm{~min}$ at room temperature to inhibit the associated BChE activity. AChE activity was measured by using modified Ellman assay with $1 \mathrm{mM}$ of acetylthiocholine substrate and $0.2 \mathrm{mM}$ DTP as chromogen [42-44]. For BChE activity assay, blood or tissue samples were pre-incubated with $400 \mathrm{nM}$ of huperzine $\mathrm{A}$ for $30 \mathrm{~min}$, followed by modified Ellman assay with $1 \mathrm{mM}$ of butyrylthiocholine as substrate and $0.2 \mathrm{mM}$ DTP as the chromogen [42-44]. The change in activity was measured at $412 \mathrm{~nm}$ for $5 \mathrm{~min}$ in a kinetic mode using a SpectraMax M5 spectrophotometer.

Total protein levels in diluted whole blood and brain tissue extracts were determined by BCA protein assay kit. The activity of enzymes in whole blood and brain extracts was expressed as units/ mg protein.

\subsection{Respiratory dynamics}

Barometric whole body plethysmography (Buxco Electronics, Inc., Sharon, CT) was used to measure respiratory dynamics in conscious, unrestrained guinea pigs as described previously [4547]. The baseline respiratory parameters were recorded in guinea pigs before exposure and at 4 and $24 \mathrm{~h}$ recovery periods after exposure to sarin in PON1 pre-treated animals and the data were analyzed by using BioSystem XE software.

\subsection{Data analysis}

Statistical analysis was performed by using GraphPad Prism software. For the animal survival data, Fisher's exact test was employed. The respiratory dynamics and blood and tissue data were analyzed by using Mann-Whitney test. Probability $(p)$ values less than or equal to 0.05 considered as significant.

\section{Results}

\subsection{Protective efficacy of purified human and rabbit serum PON1 against sarin}

Prophylaxis treatment with purified human and rabbit serum PON1 showed significant protection against sarin inhalation exposure in guinea pigs (Table 1). $86 \%$ of the animals exposed to $846 \mathrm{mg} / \mathrm{m}^{3}$ of sarin by microinstillation inhalation exposure
Table 1

Survival data of guinea pigs exposed to sarin and soman.

\begin{tabular}{|c|c|c|c|c|}
\hline Groups & $\begin{array}{l}\text { Total number } \\
\text { of animals }\end{array}$ & Survived $^{\mathrm{a}}$ & \% Survival & $\begin{array}{l}\text { Significance } \\
\text { ( } p \text { value) }\end{array}$ \\
\hline \multicolumn{5}{|c|}{ Sarin $\left(846 \mathrm{mg} / \mathrm{m}^{3}\right)$} \\
\hline Control & 14 & 2 & $14 \%$ & \\
\hline HPON1 & 6 & 4 & $67 \%$ & $0.03^{*}$ \\
\hline RPON1 & 11 & 8 & $73 \%$ & $0.005^{*}$ \\
\hline \multicolumn{5}{|c|}{ Soman $\left(841 \mathrm{mg} / \mathrm{m}^{3}\right)$} \\
\hline Control & 10 & 2 & $20 \%$ & \\
\hline HPON1 & 8 & 6 & $75 \%$ & $0.05^{*}$ \\
\hline RPON1 & 7 & 5 & $71 \%$ & $0.05^{*}$ \\
\hline
\end{tabular}

a The number of animals survived for $24 \mathrm{~h}$.

- The statistical significance of guinea pigs survival was calculated using Fisher's exact test. $p$ values $\leq 0.05$ is considered as significant.

Statistically significant.

died within $15 \mathrm{~min}$. Animals pre-treated with 5 units of purified human serum PON1 and exposed to sarin 30 min later showed $67 \%$ survival rate at $24 \mathrm{~h}$. Fisher's exact test analysis of survival rate showed statistically significant change $(p=0.03)$ in the human serum PON1 pre-treated animals compared to control sarin exposed animals (Table 1). When rabbit serum PON1 (5 units) was used for the prophylactic treatment, guinea pigs showed 73\% survival rate at $24 \mathrm{~h}$, which was also statistically significant $(p=0.005)$. Control animals exposed to sarin died within $15 \mathrm{~min}$, whereas animals pre-treated with PON1 either survived for $24 \mathrm{~h}$ or died 2-6 h after sarin exposure. PON1 pre-treated animals survived for $24 \mathrm{~h}$ were active and healthy with minimum signs of toxicity from sarin exposure.

\subsection{Purified human and rabbit serum PON1 protects against soman exposure}

Animals exposed to $841 \mathrm{mg} / \mathrm{m}^{3}$ of soman showed $20 \%$ survival rate; most of the animals died within 10-15 min after agent exposure (Table 1). Prophylaxis with human serum PON1 showed $75 \%$ survival rate in guinea pigs exposed to soman, with a statistical significance of $p=0.05$, compared to soman controls. In the case of rabbit serum PON1, the survival rate after soman exposure was found to be 71\%; Fisher's exact test showed a statistical significance of $p=0.05$. Thus, both purified human and rabbit serum PON1 showed similar levels of protection against soman exposure. In both PON1 treated groups, animals survived for $24 \mathrm{~h}$ or died $4-8 \mathrm{~h}$ after soman exposure.

\subsection{PON1 prophylaxis normalizes pulse rate and blood $\mathrm{O}_{2}$ saturation in sarin and soman exposed guinea pigs}

Guinea pigs exposed to sarin showed a gradual drop in the heart rate; $40 \%$ drop was observed in the first 10 min followed by $~ 70 \%$ drop by $15 \mathrm{~min}$, before death of the animal (Fig. 1A). Purified human and rabbit serum PON1 pre-treated animals exposed to sarin also showed a gradual decrease in the pulse rate at the initial stages of the experiment up to $\sim 5 \mathrm{~min}$, and then increased significantly and maintained normal pulse rate until the end of the experiment (Fig. 1A and B). When the guinea pigs were exposed to soman, there was an immediate and significant drop of pulse rate in the first $5 \mathrm{~min}$, followed by a gradual increase up to $10 \mathrm{~min}$ and then a gradual decrease to less than $60 \%$ of normal value leading to death of the animal (Fig. 1C). Animals pre-treated with human serum PON1 and exposed to soman showed a relatively less decrease in the pulse rate at the beginning of the experiment and maintained the normal value during the course of the experiment (Fig. 1C). In the case of rabbit serum PON1 pre-treated animals exposed to soman, there was an immediate drop in the pulse rate till 5 min, followed by a significant increase to normal value by 

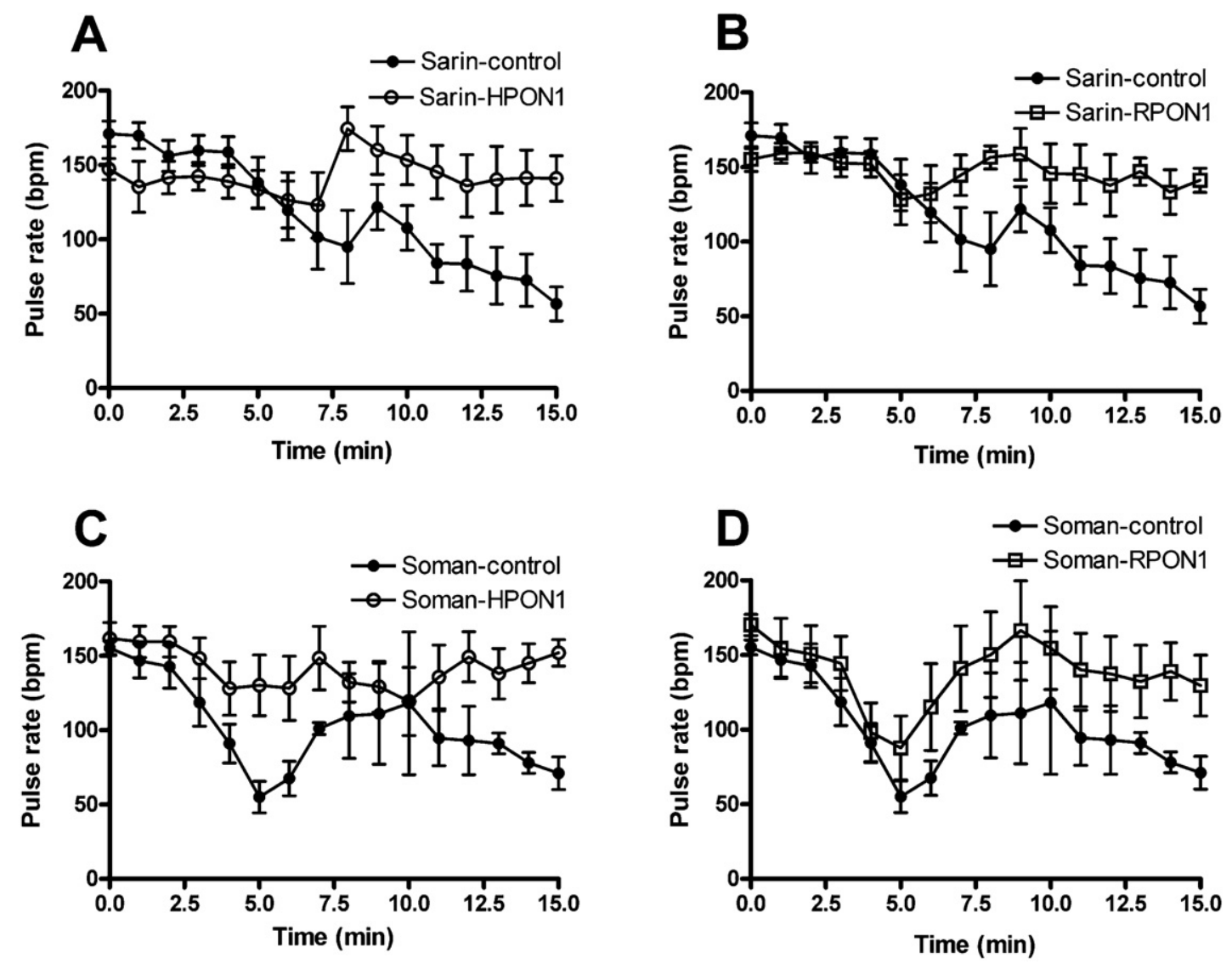

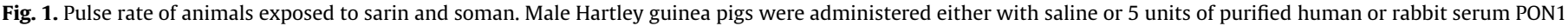

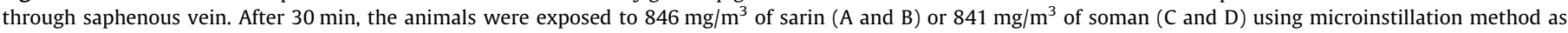

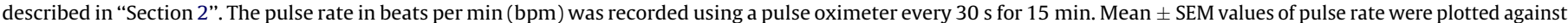

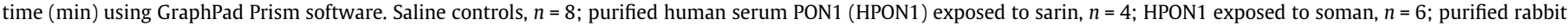
serum PON1 (RPON1) exposed to sarin, $n=8$; and RPON1 exposed to soman, $n=5$.

$7.5 \mathrm{~min}$ and that was maintained at normal levels during the 15 min recording (Fig. 1D).

The blood $\mathrm{O}_{2}$ saturation curve of sarin exposed animals showed a decrease within first $5 \mathrm{~min}$, that was returned to normal levels at $7.5 \mathrm{~min}$ and then decreased to less than $50 \%$ of normal value at 10 15 min after exposure (Fig. 2A). In the case of animals pre-treated with purified human and rabbit serum PON1 exposed to sarin, a significant drop was observed in the blood $\mathrm{O}_{2}$ saturation up to $5 \mathrm{~min}$, followed by a return to normal levels that was maintained till the end of the recording (Fig. $2 \mathrm{~A}$ and $\mathrm{B}$ ). Blood $\mathrm{O}_{2}$ saturation curves of soman exposed animals showed a similar pattern to the pulse rate, with a drop in the first $5 \mathrm{~min}$, followed by a return back to normal levels at $10 \mathrm{~min}$ and then a gradual decrease to $25 \%$ of the normal value (Fig. 2C). Human and rabbit serum PON1 pretreated animals exposed to soman also showed a drop in the $\mathrm{O}_{2}$ saturation in the first $5 \mathrm{~min}$, that was returned back to normal levels and maintained during the 15 min recordings (Fig. 2C and D). These data correlated with the increased survival rate observed with human and rabbit serum PON1 treated animals after sarin and soman exposure.

\subsection{PON1 treatment reverses respiratory functional abnormalities after sarin exposure}

Barometric whole-body plethysmography data of animals pre-treated with purified human and rabbit serum PON1 and exposed to sarin are shown in Figs. 3 and 4 . Controls with $846 \mathrm{mg} / \mathrm{m}^{3}$ sarin were not included due to the mortality of these animals, but previous data with $508 \mathrm{mg} / \mathrm{m}^{3}$ sarin were used for comparison [47]. Respiratory frequency was lower at $4 \mathrm{~h}$ after sarin exposure in PON1 treated animals compared to baseline values and was normalized at $24 \mathrm{~h}$ (Fig. 3A). Tidal volume in PON1 treated animals at 4 and $24 \mathrm{~h}$ was similar to baseline readings (Fig. 3B). Minute ventilation that was increased at $508 \mathrm{mg} / \mathrm{m}^{3}$ sarin exposure in the previous study showed normalization in PON1 treated animals (Fig. 3C). Peak inspiratory flow which showed an increase following $508 \mathrm{mg} / \mathrm{m}^{3}$ sarin exposure at $4 \mathrm{~h}$ as reported previously was decreased and was close to normal baseline in PON1 treated animals exposed to $846 \mathrm{mg} / \mathrm{m}^{3}$ sarin (Fig. 3D) [47]. Peak expiratory flow that tended to increase strongly at $4 \mathrm{~h}$ after exposure to $508 \mathrm{mg} / \mathrm{m}^{3}$ sarin changed much less in PON1 treated animals exposed to sarin (Fig. 3E). Time of inspiration $\left(T_{\mathrm{i}}\right)$ and time of expiration $\left(T_{\mathrm{e}}\right)$ that was increased at $24 \mathrm{~h}$ after $508 \mathrm{mg} / \mathrm{m}^{3}$ sarin exposure was returned to normal levels in PON1 treated animals exposed to $846 \mathrm{mg} / \mathrm{m}^{3}$ sarin (Fig. $4 \mathrm{~A}$ and B). At $4 \mathrm{~h}, T_{\mathrm{i}}$ and $T_{\mathrm{e}}$ was increased in PON1 treated animals exposed to $846 \mathrm{mg} / \mathrm{m}^{3}$ sarin, whereas $508 \mathrm{mg} / \mathrm{m}^{3}$ sarin exposure resulted in a decrease [47]. End inspiratory pause did not show any significant change in PON1 treated animals exposed to sarin compared to the baseline values (Fig. 4C). Meanwhile, end expiratory pause that was increased at $24 \mathrm{~h}$ after exposure to $508 \mathrm{mg} / \mathrm{m}^{3}$ sarin was normalized in PON1 administered animals exposed to $846 \mathrm{mg} / \mathrm{m}^{3}$ sarin (Fig. 4D). The decrease in Penh and Pause at $508 \mathrm{mg} / \mathrm{m}^{3}$ sarin exposure was returned to a normal level in PON1 treated animals exposed to $846 \mathrm{mg} / \mathrm{m}^{3}$ sarin at $24 \mathrm{~h}$ (Fig. $4 \mathrm{E}$ and F). At $4 \mathrm{~h}$, PON1 treated animals exposed to sarin showed increased Penh and Pause compared to baseline values. 

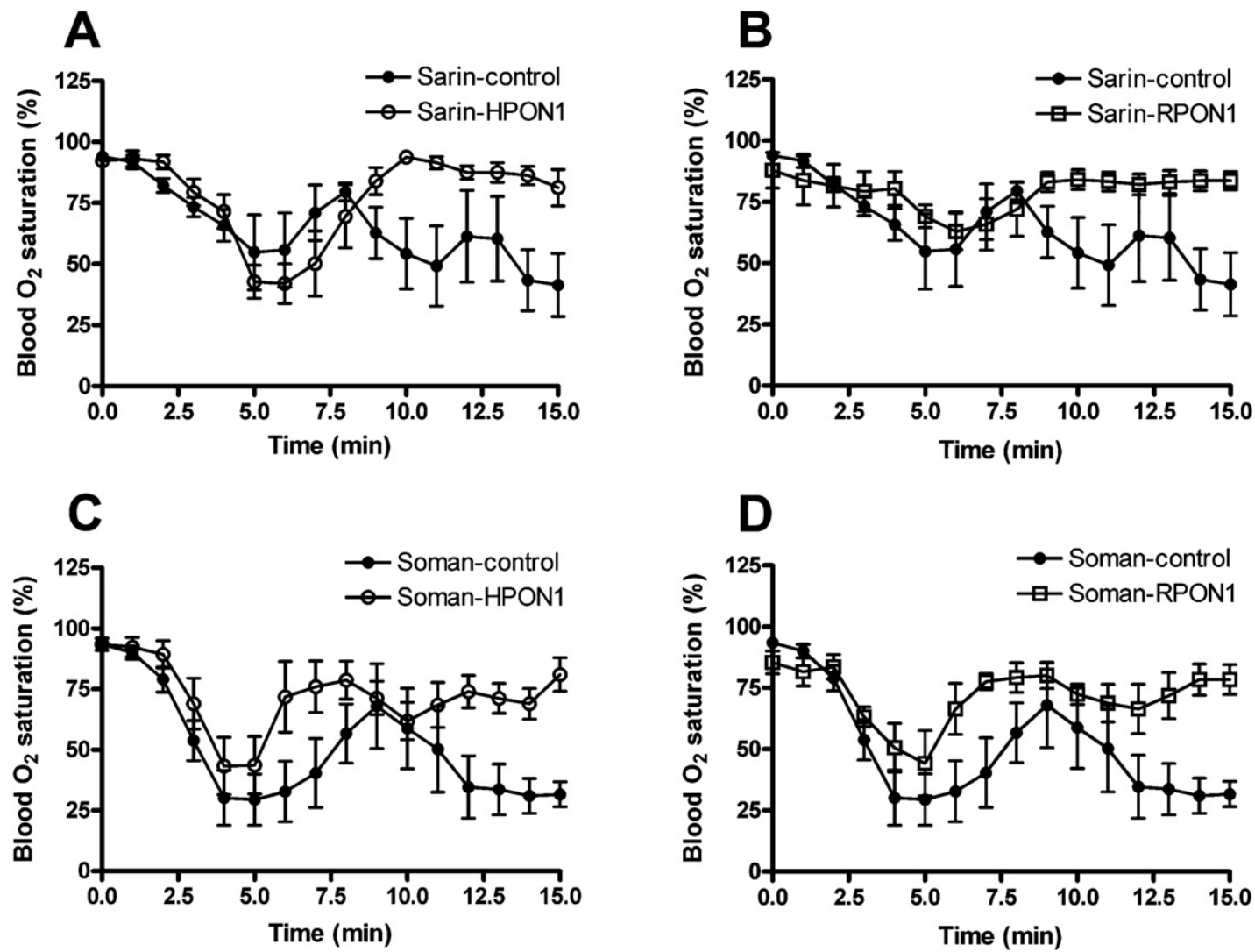

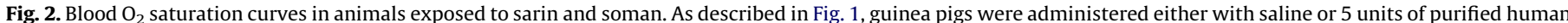

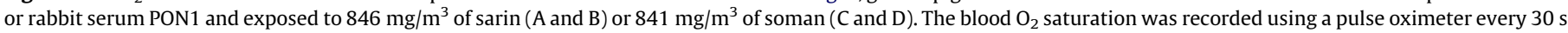

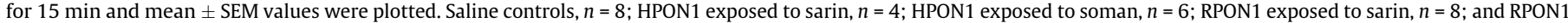
exposed to soman, $n=5$.
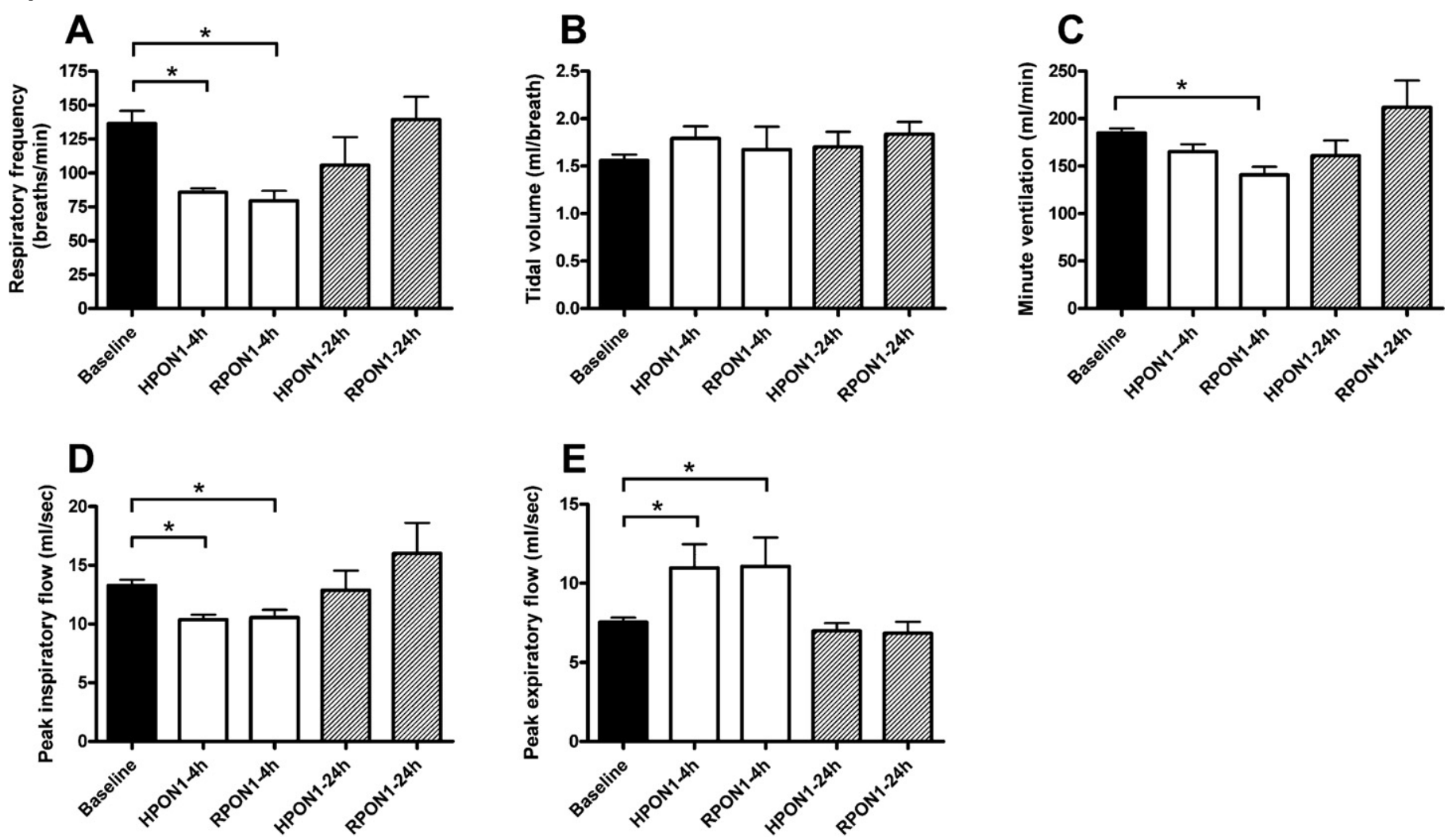

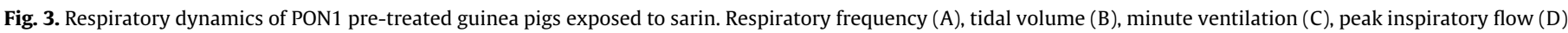

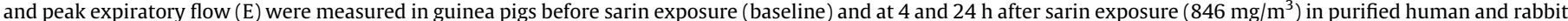
serum PONI ( 5 units) pre-treated animals as described in "Section 2". $n=6$ for baseline, 3 for HPON1 and RPON1 ( ${ }^{*} 0.05<p<0.01$ ). 

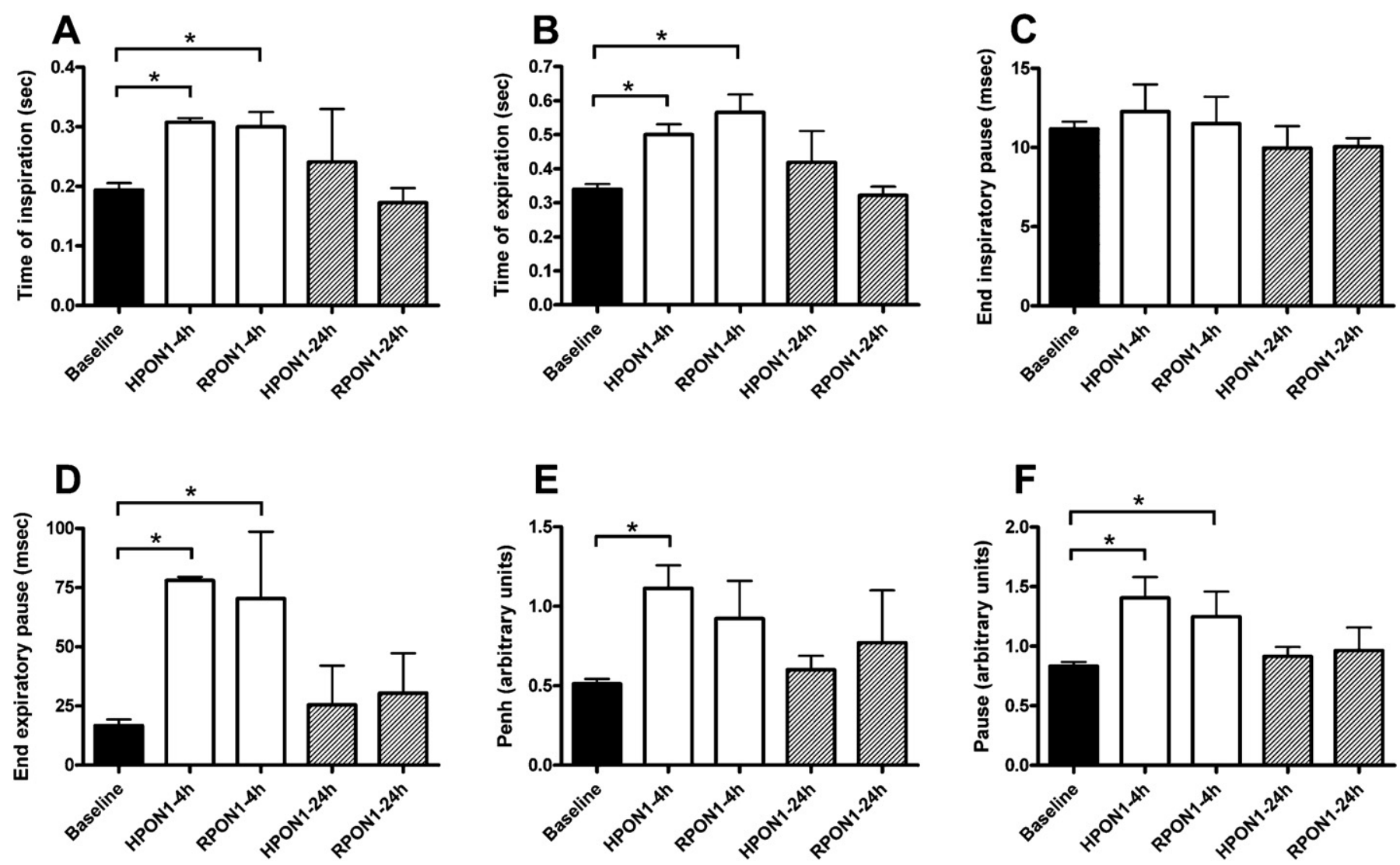

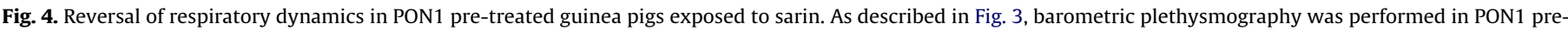

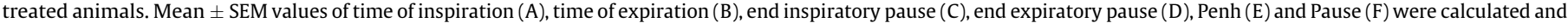
plotted using GraphPad Prism software. $n=6$ for baseline, 3 for HPON1 and RPON1 $\left({ }^{*} 0.05<p<0.01\right)$.

\subsection{Blood PON1, AChE and BChE activity in guinea pigs treated with PON1 and exposed to sarin}

Guinea pigs exposed to $846 \mathrm{mg} / \mathrm{m}^{3}$ sarin showed a significant reduction in the activity of the PON1 in the blood (Fig. 5A). Animals pre-treated with 5 units of human and rabbit serum PON1 showed a significant increase in the blood level. PON1 pre-treated animals exposed to sarin also showed a decrease in the activity of PON1 in the blood like sarin controls (Fig. 5A). However, the activity of PON1 in the pre-treated animals after sarin exposure was higher than that of sarin controls. Thus, there is a trend of higher levels of PON1 remaining in the blood of surviving animals possibly as a consequence of protection against sarin.

Blood AChE activity in sarin exposed animals was inhibited about $80 \%$ as reported earlier [48]. Animals pre-treated with both human and rabbit serum PON1 showed an increase in the activity of blood AChE, but this increase was not significant (Fig. 5B). After exposure to sarin, PON1-treated animals showed a significant decrease in the AChE activity and the resultant AChE activity was similar to normal levels in unexposed guinea pigs (Fig. 5B). Thus, the surviving animals after sarin exposure in the PON1 pre-treated group showed no significant change in the activity of blood AChE owing to the protective effects of PON1.

BChE activity in the blood of sarin exposed control animals showed a significant reduction similar to PON1 activity (Fig. 5C). The PON1 pre-treated animals did not show any significant increase in BChE activity. The decrease in the activity of blood BChE was significantly less in PON1 administered guinea pigs compared to sarin exposed controls (Fig. 5C). Exposure to sarin showed a decrease in the activity of blood BChE in human PON1 pre-treated animals, while rabbit PON1 treated animals did not show any significant reduction. These data demonstrate that animals pretreated with human and rabbit serum PON1 protect against CWNA and retain the activity of $\mathrm{BChE}$ after nerve agent exposure.

\subsection{Activity of PON1, AChE and BChE in the blood of guinea pigs treated with PON1 and exposed to soman}

Soman exposure $\left(841 \mathrm{mg} / \mathrm{m}^{3}\right)$ also significantly reduced the activity of blood PON1 activity in guinea pigs (Fig. 5D). Marginal increase in the activity of the PON1 in the blood of pre-treated animals was significantly reduced after soman exposure. The blood PON1 activity in human serum PON1 pre-treated animals after soman exposure was higher than that of soman controls, while rabbit serum PON1 pre-treated animals did not show any major change in the activity after soman exposure compared to the soman exposed controls (Fig. 5D).

As observed in the case of sarin exposure, $841 \mathrm{mg} / \mathrm{m}^{3}$ of soman exposure also showed a significant reduction in the activity of blood $\mathrm{AChE}$ ( $<80 \%$ reduction) (Fig. 5E). The PON1-induced activity of AChE was reduced after soman exposure but this decrease was significantly less compared to that seen in soman controls (Fig. 5E). Relatively higher concentration of AChE in PON1 pre-treated animals after soman exposure can be attributed to the protective efficacy of exogenous PON1 and that contributes to the increased survival of these animals.

Analysis of blood BChE activity in soman exposed guinea pigs showed results more or less similar to that observed with sarin exposure. The activity of blood BChE was significantly reduced after soman exposure (Fig. 5F). Pre-treatment with purified PON1 did not affect the BChE activity, but caused a significant reduction in this activity after exposure to soman. Compared to soman 

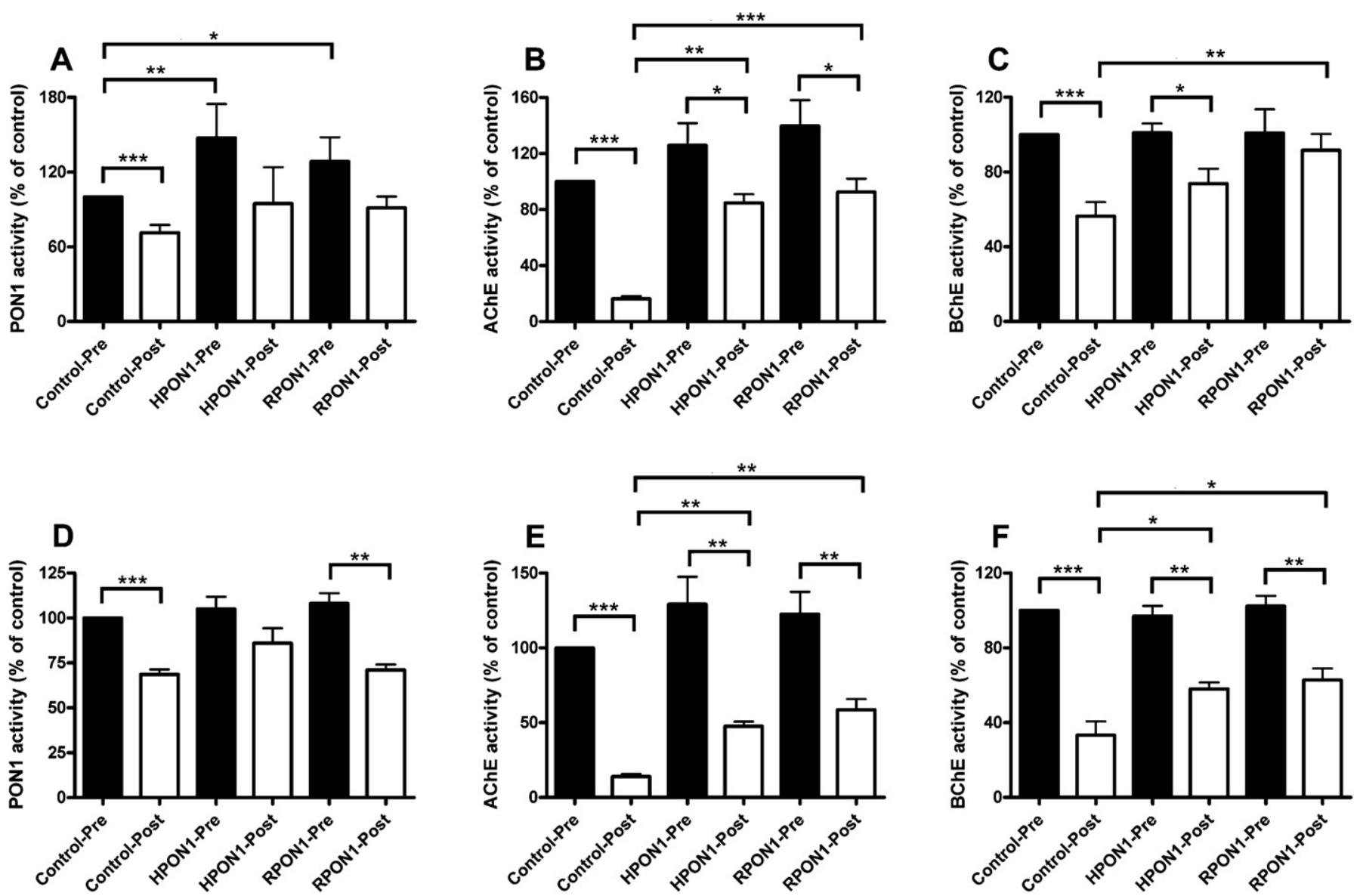

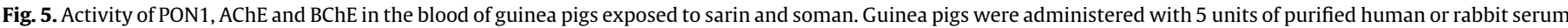

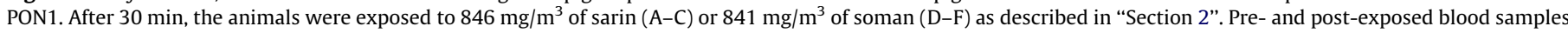

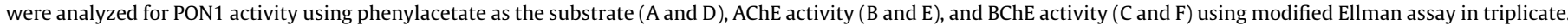

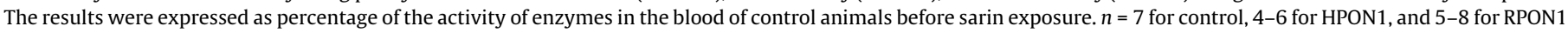
$\left({ }^{*} 0.05<p<0.01 ;{ }^{* *} 0.01<p<0.001 ;{ }^{* * *} p<0.001\right)$.

controls, the blood BChE activity was significantly higher in PON1 pre-treated animals after soman exposure (Fig. 5F). The data with soman exposure resembles that of sarin, demonstrating that pretreatment with purified PON1 can result in the retention of $\mathrm{BChE}$ activity.

\subsection{AChE activity in different regions of brain in sarin and soman exposed guinea pigs}

AChE activity in the brain of control untreated animals and sarin and soman exposed animals with and without PON1 administration is expressed as percentage of control unexposed animals (Fig. 6). The observed data showed 70-90\% inhibition of AChE activity in the frontal cortex of animals exposed to sarin and soman compared to unexposed controls (Fig. 6A). AChE activity in the frontal cortex of PON1 treated animals exposed to sarin showed an increase compared to unexposed controls (significant in the case of rabbit PON1). PON1 treated animals exposed to sarin and soman showed significant increase in AChE activity and the values are near to unexposed animals compared to sarin and soman controls (Fig. 6A). Similar levels of AChE activity were observed in the hind cortex in PON1 treated animals exposed to sarin and soman (Fig. 6B). AChE activity in the cerebellum of PON1 treated sarin and soman exposed animals was significantly higher than sarin and soman controls (Fig. 6C). However, unlike the cortex, the AChE activity in the cerebellum of PON1 treated animals exposed to sarin was not higher than the unexposed controls (compare Fig. 6C with Fig. 6A and B). Midbrain and hippocampus also showed very similar results to that of cerebellum with AChE activity in PON1 administered sarin and soman exposed animals (Fig. 6D and E).

\section{Discussion}

The present study demonstrates that administration of exogenous serum purified human and rabbit PON1 significantly protects against lethal $\left(1.2 \times \mathrm{LCt}_{50}\right)$ exposure of soman and sarin in guinea pigs. The protective efficacy was observed with respect to survival, blood $\mathrm{O}_{2}$ saturation, pulse rate, respiratory dynamics and increased levels of blood and brain cholinesterase activity. Although, both human and rabbit serum PON1 showed protection against the nerve agents, the efficacy of rabbit serum PON1 was albeit higher than human serum PON1 in sarin exposed animals probably owing to the higher catalytic efficiency of rabbit PON1 $[26,49]$. Increased activity of rabbit PON1 has been described early and it has been attributed to the presence of Lys 192 in rabbit PON1 [49]. On the other hand, soman exposed animals showed a very similar level of protective efficacy with human or rabbit serum PON1. Preliminary studies with lower doses of PON1 did not show effective protection against sarin and soman exposure using this model (data not shown). Higher doses of PON1 (more than 5 units) was not investigated in the present study.

The microinstillation inhalation exposure technology used for sarin and soman exposure is a method that is simple, requires less agent, and results in accurate dosing [36,37]. The $\mathrm{LCt}_{50}$ dose of sarin and soman was taken from our previous studies which resulted in similar percentages of mortality [40,41]. A minor 

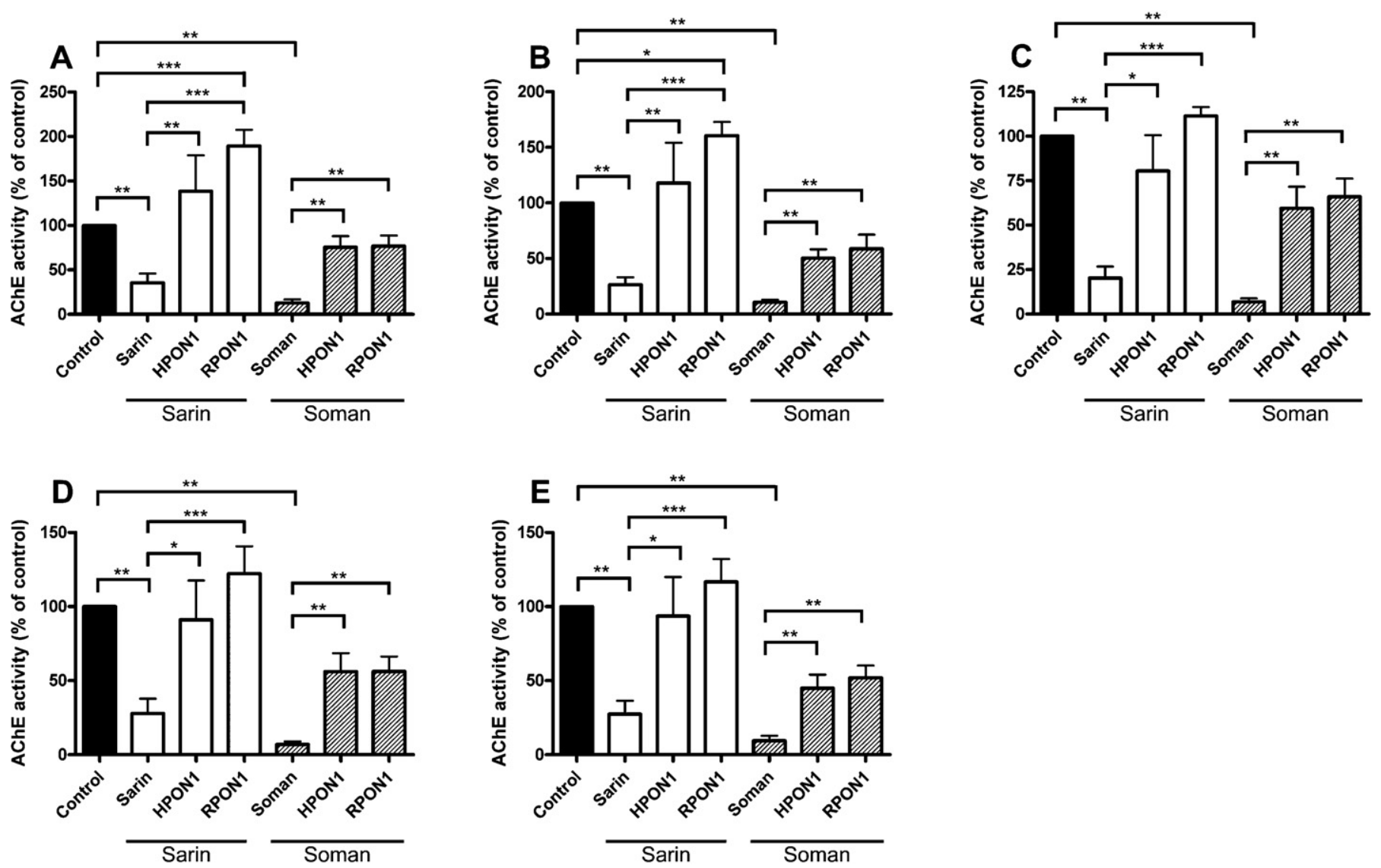

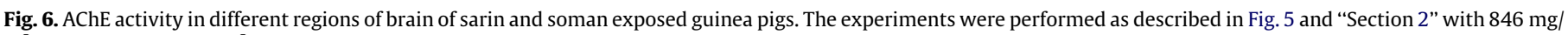

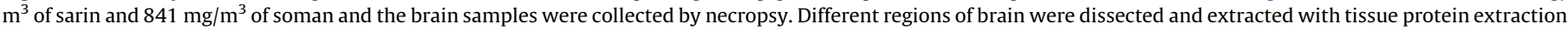

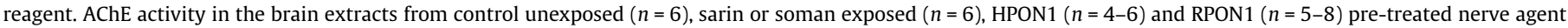

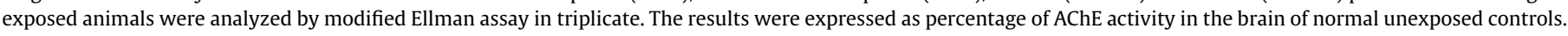

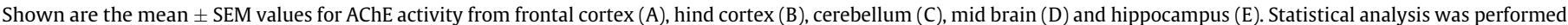
by using Mann-Whitney test $\left({ }^{*} 0.05<p<0.01\right.$; $\left.{ }^{* *} 0.01<p<0.001 ;{ }^{* * *} p<0.001\right)$.

change in the mortality may be due to the handling and administration of intravascular saline to all control animals similar to PON1 administration. Blood drawn at $30 \mathrm{~min}$ after PON1 administration showed an increase in the level of PON1 activity with a large variation (20-70\%). Currently it is not known that how rapidly exogenous PON1 is cleared from the circulation of guinea pigs. Recently it has been reported that administration of IgGPON1 fusion protein in Rhesus monkeys showed a rapid removal from circulation primarily by the liver [50]. Interestingly, our results show that the activity of AChE was increased after PON1 administration. However, purified PON1 did not show any AChE activity suggesting that the increase in AChE activity in PON1 pretreated animals is not due to any contaminating $A C h E$ in the purified PON1 samples. A similar increase in AChE activity was also found in the cortex of PON1 treated animals exposed to sarin. This might be due to the residual blood present in the cortex in nonperfused animals since other brain regions did not show any such increase in AChE activity in PON1 treated animals exposed to sarin. The mechanism underlying the increase in the activity of AChE after PON1 administration is not clear. It might be due to any possible association between these enzymes or the interaction of PON1 with unknown targets that leads to increased AChE activity. Association of AChE and PON1 has been reported earlier [51-53]. Paradoxically, soman exposed animals did not show such an increase in the cortex probably due to the rapid aging of soman coupled AChE [54,55]. Invariably, AChE activity was significantly higher and close to normal levels in PON1 treated animals exposed sarin or soman indicating that administered exogenous PON1 hydrolyzes the nerve agent before it reaches the brain.

The AChE level in the blood and brain of PON1 treated guinea pigs exposed to sarin and soman showed significantly higher activity compared to corresponding agent exposed animals. Recently, we demonstrated the catalytic efficiency of human and rabbit serum purified PON1 against several CWNAs, including sarin and soman [26]. By in vitro analysis, we found that purified human and rabbit serum PON1 could hydrolyze sarin more efficiently than soman. The current in vivo protective efficacy of PON1 correlates with our published in vitro data showing that PON1 can hydrolyze sarin better than soman.

Whole-blood BChE activity was not modulated to the extent of AChE in PON1-treated animals with or without nerve agent exposure. There was no trend of increased BChE activity in the blood after PON1 administration unlike AChE. After nerve agent exposure, the BChE level remains higher in PON1 treated animals compared to controls, although it is not close to normal levels. BChE level in rabbit PON1 treated animals exposed to sarin was higher than human PON1 treated animals, but such a difference was not observed with soman exposure.

After sarin exposure, pulse rate decreased around $5 \mathrm{~min}$ and was further reduced during the $15 \mathrm{~min}$ recording. Both serum purified human and rabbit PON1 protected against the reduction and the levels were closer to baseline during the $15 \mathrm{~min}$ recording indicating strong protection against the nerve agents. Soman resulted in sharper reduction in pulse rate than sarin and that was 
reversed by treatment with PON1. The initial reduction of pulse rate in PON1 pre-treated animals could be an acute response to the agent exposure, but the reduction in later time points in animals that gradually die after agent exposure was abolished by PON1 pretreatment. PON1 treatment also prevented the peak reduction of blood $\mathrm{O}_{2}$ saturation as well as maintained the blood $\mathrm{O}_{2}$ saturation levels throughout the $15 \mathrm{~min}$ recording in sarin exposed animals unlike the gradual decrease in control animals. The decrease in blood $\mathrm{O}_{2}$ saturation is more severe in soman exposed animals and that was minimal in PON1 treated animals exposed to soman and was closer to normal after $8 \mathrm{~min}$ when there is a sharp reduction in control animals that eventually died. This indicates that the airblood barrier and $\mathrm{O}_{2}$ exchange is maintained in animals treated with PON1 after exposure.

Respiratory physiology was also remained closer to normal in animals treated with PON1 and exposed to sarin. We have reported that microinstillation inhalation exposure to $508 \mathrm{mg} /$ $\mathrm{m}^{3}$ sarin results in a significant increase in respiratory frequency, tidal volume, minute ventilation, peak inspiratory flow and expiratory flow at $4 \mathrm{~h}$ after exposure [47]. Both human and rabbit serum PON1 treated animals did not show any significant increase in the above respiratory dynamics parameters after exposure to $846 \mathrm{mg} / \mathrm{m}^{3}$ sarin at $24 \mathrm{~h}$, indicating that PON1 treatment prevents the sarin induced changes in respiratory dynamics. Pseudo-lung resistance (Penh) and Pause that was reduced in animals exposed to $508 \mathrm{mg} / \mathrm{m}^{3}$ sarin at $24 \mathrm{~h}$ abolished in animals treated with PON1 and exposed to $846 \mathrm{mg} /$ $\mathrm{m}^{3}$ sarin [47]. Rabbit PON1 also showed a very similar protective efficacy with regard to respiratory dynamics. These results suggest that PON1 treatment may be protecting against any central respiratory depression due to nerve agent exposure that can lead to respiratory toxicity.

The observed protective efficacy of purified human and rabbit serum PON1 with an average activity of 5 units of enzyme in guinea pigs against sarin and soman is highly promising. 5 units of purified PON1 correspond to $\sim 0.5-1 \mathrm{mg}$ of enzyme per animal ( $\sim 2-4 \mathrm{mg} /$ $\mathrm{kg}, \mathrm{i} . \mathrm{v}$.), which can protect $1.2 \times \mathrm{LCt}_{50}$ of nerve agents. One of the major concerns in the prophylaxis of PON1 is the half-life of the protein in the in vivo system. In our experiments with guinea pigs, we could find only a mild to moderate increase in the activity of blood PON1 (20-70\%) after administration of exogenous PON1. However, this increase in PON1 activity was able to protect the animals against $1.2 \times \mathrm{LCt}_{50}$ doses of nerve agents. Experiment with higher doses of PON1 enzymes and challenging with $2-5 \times \mathrm{LCt}_{50}$ nerve agents is yet to be analyzed. Another alternate approach is to induce the expression of PON1 using pharmacological and dietary modulators of PON1, which are reported to increase the activity of PON1 about 2-3 fold endogenously and may have longer half-life than purified enzyme [56-59]. Recent review by Costa et al. addresses this as an approach of great promise and to be pursued in parallel [60]. Design and synthesis of recombinant PON1 with higher catalytic efficiency against CWNAs will also aid in the development of more efficient prophylaxis with relatively lower concentration of enzyme for adequate protection against 2$5 \times \mathrm{LCt}_{50}$ of CWNAs. Taken together, a combination therapy with endogenous induction of PON1 followed by exogenous administration of PON1 with higher catalytic activity can be considered as an ideal approach to overcome the existing concerns in the therapeutic candidacy of PON1 against lethal doses of nerve agent toxicity.

\section{Conflict of interest statement}

Authors declare that there are no financial or personal conflicts of interest.

\section{Acknowledgement}

This work was supported by funding from Defense Threat Reduction Agency (DTRA) Grant \#1.D0017_08_WR_C.

\section{References}

[1] Aldridge WN, Davison AN. The mechanism of inhibition of cholinesterases by organophosphorus compounds. Biochem J 1953;55:763-6.

[2] Flynn CJ, Wecker L. Elevated choline levels in brain. A non-cholinergic component of organophosphate toxicity. Biochem Pharmacol 1986;35:3115-21.

[3] Bajgar J. Organophosphates/nerve agent poisoning: mechanism of action, diagnosis, prophylaxis, and treatment. Adv Clin Chem 2004;38:151-216.

[4] Haigh JR, Johnston SR, Peters BM, Doctor BP, Gordon RK, Adler M, et al. Inhibition of guinea pig hemi-diaphragm acetylcholinesterase activity by pyridostigmine bromide and protection against soman toxicity. Chem Biol Interact 2005;157-158:381-2.

[5] Kadriu B, Guidotti A, Costa E, Auta J. Imidazenil, a non-sedating anticonvulsant benzodiazepine, is more potent than diazepam in protecting against DFPinduced seizures and neuronal damage. Toxicology 2009;256:164-74.

[6] Shih TM, Rowland TC, McDonough JH. Anticonvulsants for nerve agent-induced seizures: the influence of the therapeutic dose of atropine. J Pharmacol Exp Ther 2007;320:154-61.

[7] Koplovitz I, Stewart JR. A comparison of the efficacy of HI6 and 2-PAM against soman, tabun, sarin, and VX in the rabbit. Toxicol Lett 1994;70:269-79.

[8] Lenz DE, Maxwell DM, Koplovitz I, Clark CR, Capacio BR, Cerasoli DM, et al. Protection against soman or VX poisoning by human butyrylcholinesterase in guinea pigs and cynomolgus monkeys. Chem Biol Interact 2005;157158:205-10.

[9] Doctor BP, Saxena A. Bioscavengers for the protection of humans against organophosphate toxicity. Chem Biol Interact 2005;157-158:167-71.

[10] Doctor BP, Raveh L, Wolfe AD, Maxwell DM, Ashani Y. Enzymes as pretreatment drugs for organophosphate toxicity. Neurosci Biobehav Rev $1991 ; 15: 123-8$.

[11] Stevens RC, Suzuki SM, Cole TB, Park SS, Richter RJ, Furlong CE. Engineered recombinant human paraoxonase 1 (rHuPON1) purified from Escherichia coli protects against organophosphate poisoning. Proc Natl Acad Sci USA 2008;105:12780-4.

[12] Costa LG, Cole TB, Vitalone A, Furlong CE. Measurement of paraoxonase (PON1) status as a potential biomarker of susceptibility to organophosphate toxicity. Clin Chim Acta 2005;352:37-47.

[13] Furlong CE, Cole TB, Walter BJ, Shih DM, Tward A, Lusis AJ, et al. Paraoxonase 1 (PON1) status and risk of insecticide exposure. J Biochem Mol Toxicol 2005;19:182-3.

[14] Mackness B, Beltran-Debon R, Aragones G, Joven J, Camps J, Mackness M. Human tissue distribution of paraoxonases 1 and 2 mRNA. IUBMB Life 2010;62:480-2.

[15] Hashim Z, Ilyas A, Saleem A, Salim A, Zarina S. Expression and activity of paraoxonase 1 in human cataractous lens tissue. Free Radic Biol Med 2009;46:1089-95.

[16] Primo-Parmo SL, Sorenson RC, Teiber J, La Du BN. The human serum paraoxonase/arylesterase gene (PON1) is one member of a multigene family. Genomics 1996;33:498-507.

[17] Josse D, Masson P. Human plasma paraoxonase (HuPON1): an anti-atherogenic enzyme with organophosphate hydrolase activity. Ann Pharm Fr 2001;59:108-18

[18] Furlong CE, Richter RJ, Chapline C, Crabb JW. Purification of rabbit and human serum paraoxonase. Biochemistry 1991;30:10133-40.

[19] Hassett C, Richter RJ, Humbert R, Chapline C, Crabb JW, Omiecinski CJ, et al. Characterization of cDNA clones encoding rabbit and human serum paraoxonase: the mature protein retains its signal sequence. Biochemistry 1991;30:10141-9.

[20] Furlong CE, Costa LG, Hassett C, Richter RJ, Sundstrom JA, Adler DA, et al. Human and rabbit paraoxonases: purification, cloning, sequencing, mapping and role of polymorphism in organophosphate detoxification. Chem Biol Interact 1993;87:35-48.

[21] Humbert R, Adler DA, Disteche CM, Hassett C, Omiecinski CJ, Furlong CE. The molecular basis of the human serum paraoxonase activity polymorphism. Nat Genet 1993;3:73-6.

[22] Costa LG, Cole TB, Furlong CE. Polymorphisms of paraoxonase (PON1) and their significance in clinical toxicology of organophosphates. J Toxicol Clin Toxicol 2003;41:37-45

[23] Watson CE, Draganov DI, Billecke SS, Bisgaier CL, La Du BN. Rabbits possess a serum paraoxonase polymorphism similar to the human Q192R. Pharmacogenetics 2001;11:123-34.

[24] Otto TC, Harsch CK, Yeung DT, Magliery TJ, Cerasoli DM, Lenz DE. Dramatic differences in organophosphorus hydrolase activity between human and chimeric recombinant mammalian paraoxonase-1 enzymes. Biochemistry 2009;48:10416-22.

[25] Otto TC, Kasten SA, Kovaleva E, Liu Z, Buchman G, Tolosa M, et al. Purification and characterization of functional human paraoxonase- 1 expressed in Trichoplusia ni larvae. Chem Biol Interact 2010;187:388-92.

[26] Valiyaveettil M, Alamneh Y, Biggemann L, Soojhawon I, Doctor BP, Nambiar MP. Efficient hydrolysis of the chemical warfare nerve agent tabun by recom- 
binant and purified human and rabbit serum paraoxonase 1. Biochem Biophys Res Commun 2010;403:97-102.

[27] Li WF, Furlong CE, Costa LG. Paraoxonase protects against chlorpyrifos toxicity in mice. Toxicol Lett 1995;76:219-26.

[28] Shih DM, Gu L, Xia YR, Navab M, Li WF, Hama S, et al. Mice lacking serum paraoxonase are susceptible to organophosphate toxicity and atherosclerosis. Nature 1998;394:284-7.

[29] Fu AL, Wang YX, Sun MJ. Naked DNA prevents soman intoxication. Biochem Biophys Res Commun 2005;328:901-5.

[30] Cowan J, Sinton CM, Varley AW, Wians FH, Haley RW, Munford RS. Gene therapy to prevent organophosphate intoxication. Toxicol Appl Pharmacol 2001;173:1-6.

[31] Duysen EG, Parikh K, Aleti V, Manne V, Lockridge O, Chilukuri N. Adenovirusmediated human paraoxonase 1 gene transfer to provide protection against the toxicity of the organophosphorus pesticide toxicant diazoxon. Gene Ther 2010. doi: 10.1038/gt.2010.136.

[32] Li WF, Costa LG, Richter RJ, Hagen T, Shih DM, Tward A, et al. Catalytic efficiency determines the in-vivo efficacy of PON1 for detoxifying organophosphorus compounds. Pharmacogenetics 2000;10:767-79.

[33] Richter RJ, Jarvik GP, Furlong CE. Paraoxonase 1 (PON1) status and substrate hydrolysis. Toxicol Appl Pharmacol 2009;235:1-9.

[34] Gaidukov L, Bar D, Yacobson S, Naftali E, Kaufman O, Tabakman R, et al. In vivo administration of BL-3050: highly stable engineered PON1-HDL complexes. BMC Clin Pharmacol 2009;9:18.

[35] Peng W, Zhang C, Lv H, Zhu J, Zang Y, Pang X, et al. Comparative evaluation of the protective potentials of human paraoxonase 1 and 3 against $\mathrm{CCl}_{4}$-induced liver injury. Toxicol Lett 2010;193:159-66.

[36] Nambiar MP, Wright BS, Rezk PE, Smith KB, Gordon RK, Moran TS, et al. Development of a microinstillation model of inhalation exposure to assess lung injury following exposure to toxic chemicals and nerve agents in Guinea pigs. Toxicol Mech Methods 2006;16:295-306.

[37] Nambiar MP, Gordon RK, Moran TS, Richards SM, Sciuto AM. A simple method for accurate endotracheal placement of an intubation tube in Guinea pigs to assess lung injury following chemical exposure. Toxicol Mech Methods 2007; 17:385-92.

[38] Rodrigo L, Mackness B, Durrington PN, Hernandez A, Mackness MI. Hydrolysis of platelet-activating factor by human serum paraoxonase. Biochem 2001;354:1-7.

[39] Gan KN, Smolen A, Eckerson HW, La Du BN. Purification of human serum paraoxonase/arylesterase. Evidence for one esterase catalyzing both activities. Drug Metab Dispos 1991;19:100-6.

[40] Che MM, Conti M, Boylan M, Sciuto AM, Gordon RK, Nambiar MP. Blood and bronchoalveolar lavage fluid acetylcholinesterase levels following microinstillation inhalation exposure to sarin in Guinea pigs. Inhal Toxicol 2008;20:821-8

[41] Perkins MW, Pierre Z, Rezk P, Sabnekar P, Kabra K, Chanda S, et al. Acute respiratory toxicity following inhalation exposure to soman in guinea pigs. Toxicol Appl Pharmacol 2010;245:171-8.

[42] Ellman GL, Courtney KD, Andres Jr V, Feather-Stone RM. A new and rapid colorimetric determination of acetylcholinesterase activity. Biochem Pharmacol 1961;7:88-95.

[43] Augustinsson KB, Eriksson H, Faijersson Y. A new approach to determining cholinesterase activities in samples of whole blood. Clin Chim Acta 1978;89:239-52.
[44] Donovan DA, Zinkl JG. Modifications of a cholinesterase method for determination of erythrocyte cholinesterase activity in wild mammals. J Wildl Dis 1994;30:234-40.

[45] Rezk PE, Graham JR, Moran TS, Gordon RK, Sciuto AM, Doctor BP, et al. Acute toxic effects of nerve agent VX on respiratory dynamics and functions following microinsillation inhalation exposure in guinea pigs. Inhal Toxicol 2007; 19:291-302.

[46] Katos AM, Conti M, Moran TS, Chon TW, Gordon RK, Sciuto AM, et al. Acute microinstillation inhalation exposure to soman induces changes in respiratory dynamics and functions in guinea pigs. Inhal Toxicol 2009;21:1-10.

[47] Conti ML, Che MM, Boylan M, Sciuto AM, Gordon RK, Nambiar MP. Acute microinstillation inhalation exposure to sarin induces changes in respiratory dynamics and functions in guinea pigs. Int $\mathrm{J}$ Toxicol 2009;28:436-47.

[48] Shih TM, Kan RK, McDonough JH. In vivo cholinesterase inhibitory specificity of organophosphorus nerve agents. Chem Biol Interact 2005;157-158:293303.

[49] Aharoni A, Gaidukov L, Yagur S, Toker L, Silman I, Tawfik DS. Directed evolution of mammalian paraoxonases PON1 and PON3 for bacterial expression and catalytic specialization. Proc Natl Acad Sci USA 2004;101:482-7.

[50] Boado RJ, Hui EK, Lu JZ, Pardridge WM. CHO cell expression, long-term stability, and primate pharmacokinetics and brain uptake of an IgG-paroxonase-1 fusion protein. Biotechnol Bioeng 2011;108:186-96.

[51] Akgur SA, Ozturk P, Sozmen EY, Delen Y, Tanyalcin T, Ege B. Paraoxonase and acetylcholinesterase activities in humans exposed to organophosphorous compounds. J Toxicol Environ Health A 1999;58:469-74.

[52] BenMoyal-Segal L, Vander T, Shifman S, Bryk B, Ebstein RP, Marcus EL, et al. Acetylcholinesterase/paraoxonase interactions increase the risk of insecticide-induced Parkinson's disease. FASEB J 2005;19:452-4.

[53] Sklan EH, Lowenthal A, Korner M, Ritov Y, Landers DM, Rankinen T, et al. Acetylcholinesterase/paraoxonase genotype and expression predict anxiety scores in health, risk factors, exercise training, and genetics study. Proc Natl Acad Sci USA 2004;101:5512-7.

[54] Worek F, Aurbek N, Koller M, Becker C, Eyer P, Thiermann H. Kinetic analysis of reactivation and aging of human acetylcholinesterase inhibited by different phosphoramidates. Biochem Pharmacol 2007;73:1807-17.

[55] Shafferman A, Ordentlich A, Barak D, Stein D, Ariel N, Velan B. Aging of somanyl-acetylcholinesterase adducts: facts and models. Biochem J 1997;324(Pt 3):996-8.

[56] Costa LG, Vitalone A, Cole TB, Furlong CE. Modulation of paraoxonase (PON1) activity. Biochem Pharmacol 2005;69:541-50.

[57] Gouedard C, Barouki R, Morel Y. Induction of the paraoxonase-1 gene expression by resveratrol. Arterioscler Thromb Vasc Biol 2004;24:2378-83.

[58] Gouedard C, Koum-Besson N, Barouki R, Morel Y. Opposite regulation of the human paraoxonase-1 gene PON-1 by fenofibrate and statins. Mol Pharmacol 2003;63:945-56.

[59] Boesch-Saadatmandi C, Egert S, Schrader C, Coumol X, Barouki R, Muller MJ, et al. Effect of quercetin on paraoxonase 1 activity-studies in cultured cells, mice and humans. J Physiol Pharmacol 2010;61:99-105.

[60] Costa LG, Giordano G, Furlong CE. Pharmacological and dietary modulators of paraoxonase 1 (PON1) activity and expression: the hunt goes on. Biochem Pharmacol 2011;81:337-44. 